\title{
Effect of inhibitors of histone deacetylase on the induction of cell differentiation in murine and human erythroleukemia cell lines
}

\author{
Sybille Wittich ${ }^{\mathrm{a}}$, Hans Scherf ${ }^{\mathrm{b}}$, Changping Xie ${ }^{\mathrm{b}}$, Birgit Heltweg ${ }^{\mathrm{a}}$, \\ Franck Dequiedt ${ }^{c, d}$, Eric Verdin ${ }^{d}$, Clarissa Gerhäuser ${ }^{b}$ and Manfred Jung ${ }^{a}$
}

\begin{abstract}
Histone deacetylase (HDAC) inhibitors are a novel class of promising anti-cancer agents. Little information is available on the capacity of structurally different HDAC inhibitors to induce terminal cell differentiation in different cell types in relation to enzyme inhibition and subtype selectivity. Consequently, the aim of this study was to provide a comprehensive comparison of these effects. New biarylalanine inhibitors of HDAC were synthesized and compared to a series of standard inhibitors from different laboratories. Chromatographically purified rat liver and immunoprecipitated FLAG-tagged recombinant human HDACs were used as sources of HDAC activity. Enzyme inhibition was studied using a fluorescent substrate and its conversion was monitored by high-performance liquid chromatography. The ability to induce cell differentiation was compared in murine (Friend DS-19) and human (K562) erythroleukemic cell lines, and was quantified by benzidine staining. Inhibition of cell proliferation was evaluated by cell counting. All HDAC inhibitors were identified as potent inhibitors of erythroleukemic cell proliferation. However, we observed a complex pattern of differentiation induction: structurally similar inhibitors resulted in disparate activity profiles, whereas similar profiles were detected within distinct structural classes. Among the newly synthesized biarylalanine compounds, a $3^{\prime}$-methoxy derivative was
\end{abstract}

\section{Introduction}

Histone deacetylase (HDAC) inhibitors are a relatively new class of potential drugs for the treatment of hyperproliferative, as well as parasitemic diseases [1,2]. Inhibition of HDAC leads to hyperacetylation of chromatin which is usually associated with transcriptional activation of a number of genes [3,4]. One of the important downstream events of histone hyperacetylation is increased expression of the cyclin-dependent kinase (cdk) inhibitory protein p21/WAF1/CIP1 resulting in cell cycle arrest [5]. The dysregulated recruitment of HDACs by oncogenic fusion proteins was identified as a general mechanism for the pathogenesis of leukemia [6,7]. Therefore, HDAC is viewed as an attractive target for anti-cancer drug development [8,9]. There are 11 subtypes known for the 'classical' zinc-dependent HDACs [10], but little is known about the subtype selectivity of established inhibitors or the biological consequences of such an inhibition. identified as a very effective inducer of terminal cell differentiation. We conclude that investigation of subtype selectivity of selected HDAC inhibitors does not provide a clear link between selectivity and the observed cellular activity profile. The predictive value of in vitro HDAC inhibition assays for identifying anti-proliferative compounds has been emphasized. Anti-Cancer Drugs 16:635-643 (c) 2005 Lippincott Williams \& Wilkins.

Anti-Cancer Drugs 2005, 16:635-643

Keywords: benzidine staining, cell differentiation, erythroleukemia, histone deacetylase, hydroxamic acid, K562, murine Friend leukemic cell

aDepartment of Pharmaceutical and Medicinal Chemistry, Westfälische Wilhelms-
Universität Münster, Münster, Germany, 'Division of Toxicology and Cancer Risk
Factors, Deutsches Krebsforschungszentrum, Heidelberg, Germany, 'Molecular
and Cellular Biology Unit, FUSAGx, Gembloux, Belgium and ${ }^{\mathrm{d}}$ Gladstone Institute
of Virology and Immunology, University of California, San Francisco, CA, USA.

Sponsorship: Funding by the Deutsche Forschungsgemeinschaft (Ju295/2) is gratefully acknowledged. C. G. was supported by the Verein zur Förderung der Krebsforschung in Deutschland eV.

Correspondence to M. Jung, Institute of Pharmaceutical Sciences, University of Freiburg, Albertstrasse 25, 79104 Freiburg, Germany. Tel: +49761203 4896; fax: +49761203 6321;

e-mail: manfred.jung@pharmazie.uni-freiburg.de

Received 9 November 2004 Revised form accepted 29 March 2005

We had previously proposed a general model for HDAC inhibitors that was derived from the potent natural product inhibitors trapoxin B (TPX) and trichostatin A (TSA) [11], and had accordingly developed the first simple potent inhibitors of HDAC [12]. Structureactivity studies have led to the improved inhibitor BIP1 with a biphenylalanine instead of a phenylalanine moiety [13]. Here, we present a set of substituted biphenylalanines BIP2-6 that were synthesized in order to elucidate whether HDAC inhibitory activity is dependent on electronic properties in the biaryl moiety. We report in vitro inhibition of rat liver HDAC activity as well as antiproliferative and differentiation-inducing effects in murine Friend leukemic cells (MELC) and the human K562 cell line. We also present a comparison of a series of structurally diverse standard HDAC inhibitors in these two erythroleukemic cell lines. Finally, selected inhibitors were tested for their subtype selectivity concerning HDACs 1,3 and 6. 


\section{Materials and methods Chemicals}

For further modification of our biphenylalanine lead compound we used the strategy that was used previously for similar analogs [13]. As a new route for structural variations within this strategy 4-bromophenylalanine methyl ester was converted to a building block with a trityl-protected hydroxamate function that was successfully subjected to palladium-mediated biaryl coupling. This resulted in substituted biphenylalanines which were deprotected with trifluoroacetic acid/triethylsilane in order to obtain the desired hydroxamic acids BIP2-6 (see Fig. 1). We have used boronic acids as the electrophilic coupling partners and $\mathrm{Pd}(\mathrm{OAc})_{2} / \mathrm{P}(o-\text { tol })_{3}$ as the catalyst. The biaryls were isolated with yields ranging from 43 to $80 \%$. This catalytic system has been used previously for the synthesis of biarylalaninecontaining di- and tripeptides [14]. Purity and identity were assured using IR and NMR spectroscopy as well as elemental analyses. TSA, Scriptaid, SAHA and MS275 were purchased from EMD Biosciences (San Diego, CA). MD85 [12,15], M344, M360 [16] and BIP1 [13] were synthesized according to the literature. M344 is also commercially available (Alexis, Lausen, Switzerland or EMD Biosciences: histone deacetylase inhibitor III).

\section{In vitro enzyme inhibition}

Rat liver HDAC was partially purified essentially as described earlier [17,18]. An ammonium sulfate precipitation step was included for further purification prior to chromatography [19]. This preparation is commercially available (EMD Biosciences or Alexis). For testing, stock solutions of the inhibitors $(1 \mathrm{mg} / \mathrm{ml}$ in ethanol for TSA and $12 \mathrm{mM}$ in DMSO for all other inhibitors) were diluted with enzyme buffer $(15 \mathrm{mM}$ Tris-HCl, $\mathrm{pH} 7.9$, $0.25 \mathrm{mM}$ EDTA, $10 \mathrm{mM} \mathrm{NaCl}, 10 \%$ (v/v) glycerol, $10 \mathrm{mM}$ 2-mercaptoethanol).

The assay was performed as described earlier [20]. Briefly, $12 \mu \mathrm{l}$ of a solution of the substrate $(4.682 \mathrm{mg} / \mathrm{ml}$ in ethanol) and $24 \mu \mathrm{l}$ of a solution of the internal standard 7-hydroxycoumarin $(3.66 \mathrm{mg} / \mathrm{ml} \mathrm{DMSO})$ were combined and brought to a total volume of $1 \mathrm{ml}$ with enzyme buffer. An aliquot of $10 \mu \mathrm{l}$ of this stock solution was added to a mixture of $100 \mu \mathrm{l}$ (approximately $90 \mathrm{U} / \mathrm{ml} ; 1 \mathrm{U}: 1 \mathrm{pmol} /$ min) of rat enzyme preparation $\left(\right.$ at $4^{\circ} \mathrm{C}$ ) and $10 \mu \mathrm{l}$ of inhibitor dilution. After $15 \mathrm{~min}$ at $4^{\circ} \mathrm{C}$ the mixture was incubated for $90 \mathrm{~min}$ at $37^{\circ} \mathrm{C}$. Then, the reaction was stopped by addition of $72 \mu \mathrm{l}$ of $1 \mathrm{M} \mathrm{HCl} / 0.4 \mathrm{M}$ sodium acetate and $800 \mu \mathrm{l}$ of ethyl acetate. After centrifugation $(10000 \mathrm{~g}, 5 \mathrm{~min}), 200 \mu \mathrm{l}$ of the upper phase was dried under a stream of nitrogen. The residue was dissolved in $600 \mu \mathrm{l}$ of the chromatography eluent and $20 \mu \mathrm{l}$ was injected via an autosampler onto the high-performance liquid chromatography (HPLC) system. In a modification of the previously published assay $[17,18,20], 10.5 \mu \mathrm{M}$ substrate was used here instead of $3.5 \mu \mathrm{M}$, resulting in increased precision (data not shown). The amount of remaining substrate was calculated relative to the substrate control incubated without enzyme (each as quotient of the peak area of the substrate divided by the peak area of the internal standard). A Shimadzu RF 535 was used as fluorescence detector for HPLC and a LiChrosorb RP $18-5 \mu \mathrm{m}(125 \times 3 \mathrm{~mm}$; Knauer, Berlin, Germany) column was used for separation. The Biomol HDAC fluorescent activity assay kit was used according to the manufacturer's instructions. FLAG-HDAC immunoprecipitation and assays were performed as published previously [21]

\section{Induction of terminal cell differentiation}

MEL DS19 murine erythroleukemia cells (MELC) were maintained in DMEM containing $100 \mathrm{U} / \mathrm{ml}$ penicillin $\mathrm{G}$ sodium and $100 \mu \mathrm{g} / \mathrm{ml}$ streptomycin sulfate supplemented with $10 \%$ fetal bovine serum (Greiner, Frickenhausen, Germany) at $37^{\circ} \mathrm{C}$ in a $5 \% \mathrm{CO}_{2}$ atmosphere. $\mathrm{K} 562$ human erythroleukemia cells (obtained from the Tumorbank, German Cancer Research Center, Heidelberg, Germany) were maintained in RPMI medium containing $100 \mathrm{U} / \mathrm{ml}$ penicillin $\mathrm{G}$ sodium and $100 \mu \mathrm{g} / \mathrm{ml}$ streptomycin sulfate supplemented with $10 \%$ fetal bovine serum (Greiner) at $37^{\circ} \mathrm{C}$ in a $5 \% \mathrm{CO}_{2}$ atmosphere. To test compounds for potential to induce cell differentiation, log-phase cells were used. Serial dilutions of compounds were prepared in 24-well plates (Falcon) using $1 \mathrm{ml}$ medium/well. If compounds were dissolved in DMSO, control wells contained the same amount of solvent (generally $2 \mu \mathrm{l} / \mathrm{ml}$ medium, $0.1 \%$ final concentration). Subsequently, the cell suspension was added to the wells $\left(1 \mathrm{ml} /\right.$ well, $2 \times 10^{4}$ cells $/ \mathrm{ml}$; final cell concentration $1 \times 10^{4}$ cells/well). After 72 (MELC) or $96 \mathrm{~h}$ (K562), respectively, the experiment was evaluated. Cell numbers were counted using a Casy 1 TTC flow cytometer (Schärfe System, Reutlingen, Germany). The proliferation of treated cells was expressed as percent proliferation in comparison with the solvent control.

Differentiated K562 and Friend leukemic cells accumulate hemoglobin. Therefore, the induction of cell differentiation was determined by benzidine staining according to the literature [22]. To $50 \mu \mathrm{l}$ of cells suspension, an equal volume of benzidine solution $\left(2 \mathrm{mg} / \mathrm{ml}\right.$ in $0.5 \mathrm{M}$ acetic acid containing $2 \% \mathrm{H}_{2} \mathrm{O}_{2}$ ) was added. Within $5 \mathrm{~min}$ the hemoglobin-containing cells stain blue. Benzidine-positive and -negative cells were counted under the microscope in a hemocytometer, and the percentage of positive cells was calculated. All compounds were first tested at 10 and $50 \mu \mathrm{M}$ final concentrations. According to the activity/toxicity profile, a range of concentration was chosen for a dose-response analysis. In selected cases, dose-response experiments were repeated at the same concentrations and deviations were below $5 \%$. 
<smiles>CC(=C/[C@@H](C)C(=O)c1ccc(N(C)C)cc1)/C=C/C(=O)NO</smiles>

TSA<smiles>O=C(CCCCCN1C(=O)c2cccc3cccc(c23)C1=O)NO</smiles>

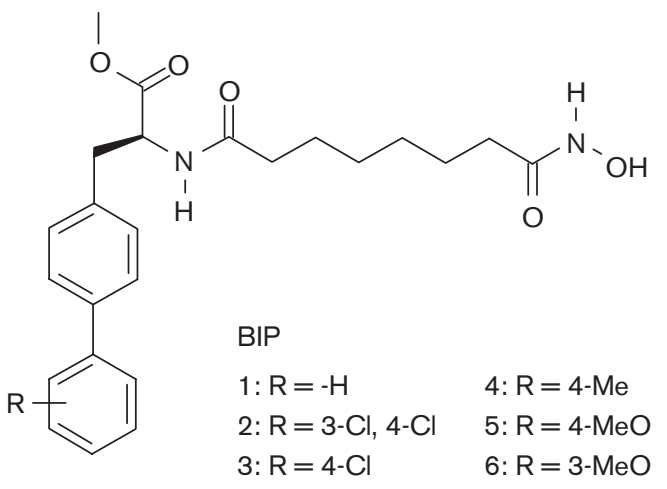<smiles>CNC(=O)NO</smiles>

MD85: $n=5$, M344: $n=6$, M360: $n=7$<smiles>O=C(CCCCCCC(=O)Nc1ccccc1)NO</smiles>

SAHA<smiles>CS(=O)(=O)NCc1ccc(C(=O)Nc2ccccc2N)cc1</smiles>

Chemical structures of tested HDAC inhibitors.

\section{Histone hyperacetylation}

$\mathrm{K} 562$ cells $\left(1 \times 10^{5}\right.$ cells $/ \mathrm{ml}$ in $\left.20 \mathrm{ml}\right)$ were incubated in RPMI for $24 \mathrm{~h}$ and then treated with BIP6 $(1.56 \mu \mathrm{M})$ or MS275 $(0.625 \mu \mathrm{M})$, respectively, for $12 \mathrm{~h}$. Control cells obtained DMSO (0.1\% final concentration). Isolation of histones, quantification of protein and acid-urea-Triton (AUT) PAGE analyses were performed as described previously [23].

\section{Results \\ HDAC inhibition}

The series of biarylalanine compounds BIP1-5 was tested for inhibition of a partially purified rat liver $\mathrm{HDAC}$ employing the fluorogenic substrate developed in our group [17,18] and enzyme inhibitory properties were compared. The substituents of these novel derivatives were selected in order to determine with a limited number of compounds whether inhibitory activity was dependent on electronic properties of the aromatic ring [24].

As BIP1 was the most potent inhibitor (see Table 1), an unfavorable steric repulsion in the $4^{\prime}$-position of the substituted compounds BIP2-5 was assumed. For substituted derivatives, the activity increased from BIP2 to BIP5, indicative for a beneficial effect of electron-donating substituents. Consequently, the $3^{\prime}$-methoxy analog BIP6 was synthesized, but this compound again was less active than the most qpotent parent compound BIP1 (see Table 1). For comparison, we included several standard HDAC inhibitors from our and other labs. We investigated TSA [25], the trichostatin analogs MD85 [12,15], M344 and M360 [16] that were synthesized previously in our group, Scriptaid [26], the so-called hybrid polar drug SAHA [27] which is in clinical trials, and the benzamide MS275 [28,29] (see Fig. 1). All $\mathrm{IC}_{50}$ values summarized in Table 1 (except for MS275) were determined under identical assay conditions. In contrast to published data, we could not detect inhibitory activity of MS275 using our methodology [30] or the commercially available Biomol kit. A similar lack of inhibition has been reported recently [31] and it was speculated by that group that in vitro inhibition by MS275 is dependent on certain cofactors that are required in the enzyme preparation. 
Table 1 In vitro rat liver HDAC inhibition in comparison with inhibition of cell proliferation of Friend murine and K562 human erythroleukemia cells by HDAC inhibitors

\begin{tabular}{lccc}
\hline Compound & $\begin{array}{c}\text { HDAC inhibition } \\
\left(\mathrm{IC}_{50}, \mu \mathrm{M} \pm \mathrm{SD}^{\mathrm{a}}\right)\end{array}$ & $\begin{array}{c}\mathrm{MEL} \text { inhibition } \\
\left(\mathrm{IC}_{50}, \mu \mathrm{M}^{\mathrm{b}}\right)\end{array}$ & $\begin{array}{c}\text { K562 inhibition } \\
\left(\mathrm{IC}_{50}, \mu \mathrm{M}^{\mathrm{b}}\right)\end{array}$ \\
\hline BIP1 & $0.29 \pm 0.03^{\mathrm{c}}$ & 0.64 & 0.04 \\
BIP2 & $0.70 \pm 0.04$ & 1.92 & 1.14 \\
BIP3 & $0.53 \pm 0.03$ & 0.46 & 0.31 \\
BIP4 & $0.45 \pm 0.06$ & 0.64 & 0.23 \\
BIP5 & $0.41 \pm 0.03$ & 0.58 & 0.20 \\
BIP5 & $0.63 \pm 0.06$ & 3.27 & 0.71 \\
TSA & $0.01 \pm 0.001^{\mathrm{d}}$ & 0.04 & 0.05 \\
MD85 & $0.22 \pm 0.02^{\mathrm{d}}$ & 9.51 & 2.20 \\
M344 & $0.12 \pm 0.01^{\mathrm{d}}$ & 1.00 & 0.34 \\
M360 & $0.20 \pm 0.02$ & 3.97 & 1.80 \\
Scriptaid & $0.06 \pm 0.02^{\mathrm{d}}$ & 9.30 & 11.8 \\
SAHA & $0.17 \pm 0.03^{\mathrm{d}}$ & 0.89 & 0.61 \\
MS275 & $\mathrm{NI}^{\mathrm{e}} / 4.8^{\mathrm{f}} / 130 \pm 18^{\mathrm{g}}$ & 1.24 & 0.31
\end{tabular}

Referenced inhibition data (except note f) was generated in our laboratory under identical conditions.

a Mean values of half-maximal inhibitory concentrations $\left(I_{50}\right) \pm S D$ were computed from four experiments.

${ }^{\mathrm{b}} \mathrm{IC}_{50}$ values were generated from testing six to eight concentrations in duplicate. 'Data taken from [13].

${ }^{\mathrm{d}}$ Data taken from [19].

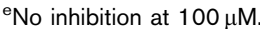

fData taken from [29].

${ }^{9}$ Data using the Biomol assay.

\section{Inhibition of proliferation and induction of terminal differentiation}

The novel HDAC inhibitors were further tested for the anti-proliferative and differentiation-inducing potential of murine Friend erythroleukemic cells and human K562 erythroleukemia cells. Friend cell differentiation has been a standard model for the investigation of HDAC inhibitors in many studies [16,32-34]. The aim of our current studies was a comparison of effects in the murine cell line with those in a human erythroleukemia cell line. In addition, the above-mentioned reference inhibitors were tested for comparative reasons. Cell differentiation was detected by an accumulation of hemoglobin which is easily visualized by benzidine staining. Figure 2 shows the profiles of cellular activity, and Table 1 summarizes $\mathrm{IC}_{50}$ values for inhibition of HDAC and cellular proliferation.

All HDAC inhibitors demonstrated dose-dependent inhibition of cell proliferation in both leukemic cell lines. Overall, the K562 cell line was more sensitive to the growth inhibitory potential of the test compounds than the Friend cell line and all compounds except Scriptaid were more toxic for the human cell line. We noticed that $\mathrm{IC}_{50}$ values from the HDAC in vitro test were of the same order of magnitude as the ones obtained in the antiproliferative tests. The biggest differences were seen with Scriptaid, which was more than 100 -fold less potent in the cellular systems. TSA was identified as the most potent compound in all three assays, but the unsubstituted biarylalanine BIP1 was equally effective in the human K562 cell line.

For the induction of terminal cell differentiation, the compounds can be arranged in three groups depending on the maximum percentage of benzidine-positive cells. In the Friend cell line, weak induction (less than $30 \%$ benzidine-positive cells) was monitored with the first group, the halogenated biaryls BIP2 and BIP3, the trichostatin analogs MD85 and M360, Scriptaid, and MS275. BIP2, MD85 and Scriptaid were weak inducers in the K562 cell line as well. The second group, consisting of the methyl biaryl BIP4, its methoxy analogs BIP5 and BIP6, TSA, and SAHA, showed a moderate differentiation induction potential in $30-50 \%$ of the surviving Friend cells. The percentage of benzidine-positive cells for BIP4 was similar in K562 cells. BIP5 was less effective in the human cell line, whereas SAHA, MS275 and the 3'methoxy compound BIP6 were identified as potent inducers of differentiation in K562 cells (above 50\%). The unsubstituted biarylalanine BIP1 and the aminoheptanoate analog of TSA (M344) were found to most potently induce terminal cell differentiation in Friend cells (above 50\%) which was reduced somewhat for BIP1 and strongly (below 30\%) for M344 in the human cell line.

\section{Histone hyperacetylation}

With compound BIP6 and the reference compound MS275 we additionally investigated the potential to induce hyperacetylation in K562 cells by AUT gel electrophoresis as described in the literature [22,23]. As outlined above, both compounds belong to the most potent group to induce differentiation in K562 cells. Both compounds led to accumulation of hyperacetylated histone H4 when K562 cells were treated for $12 \mathrm{~h}$ with $1.56 \mu \mathrm{M}$ BIP6 or with $0.625 \mu \mathrm{M}$ MS275, respectively (Fig. 3).

\section{HDAC subtype selectivity}

We have previously shown that the aminoheptanoate M344 (good inducer of MELC differentiation) is selective for HDAC6 (3-fold) [30]. On the other hand, the aminooctanoate M360 (little induction of differentiation) was slightly selective for HDAC1 [30] (see Table 2). In this report, we additionally investigated the aminocaproate MD85, and the biaryls BIP2 (little induction of differentiation) and BIP6 (good induction of differentiation) for inhibition of immunoprecipitated FLAG-tagged HDAC1 and HDAC6, using a radioactively labeled histone peptide fragment as the substrate. Data for inhibition of HDAC3 is additionally presented for all compounds.

\section{Discussion}

Here, we report the synthesis of novel biarylalanine HDAC inhibitors, which do not exceed the potency of the unsubstituted lead compound in its in vitro HDACinhibitory potency. As neither electron-donating nor electron-withdrawing substituents lead to an increase, we assume that additional substitutions of the biaryl 
moiety in BIP1 are not favorable for inhibitory activity due to steric hindrance. Possibly, the region of the enzyme that the biphenyl group binds to is quite restricted in the tolerance of inhibitors. As HDAC1, in particular, is thought to be important for mediation of cancer cell proliferation [35] and no structural data for that subtype is available, BIP1 might be an interesting candidate for docking experiments in homology models of human HDACs [36] that can be derived from the structure of the homologous bacterial histone-deacetylase-like-protein (HDLP) [37] or human HDAC8 [38].

All HDAC inhibitors that were investigated in this study were identified as strong anti-proliferative drugs in erythroleukemic cells, which emphasizes their potential as anti-cancer drugs. Especially interesting is the activity
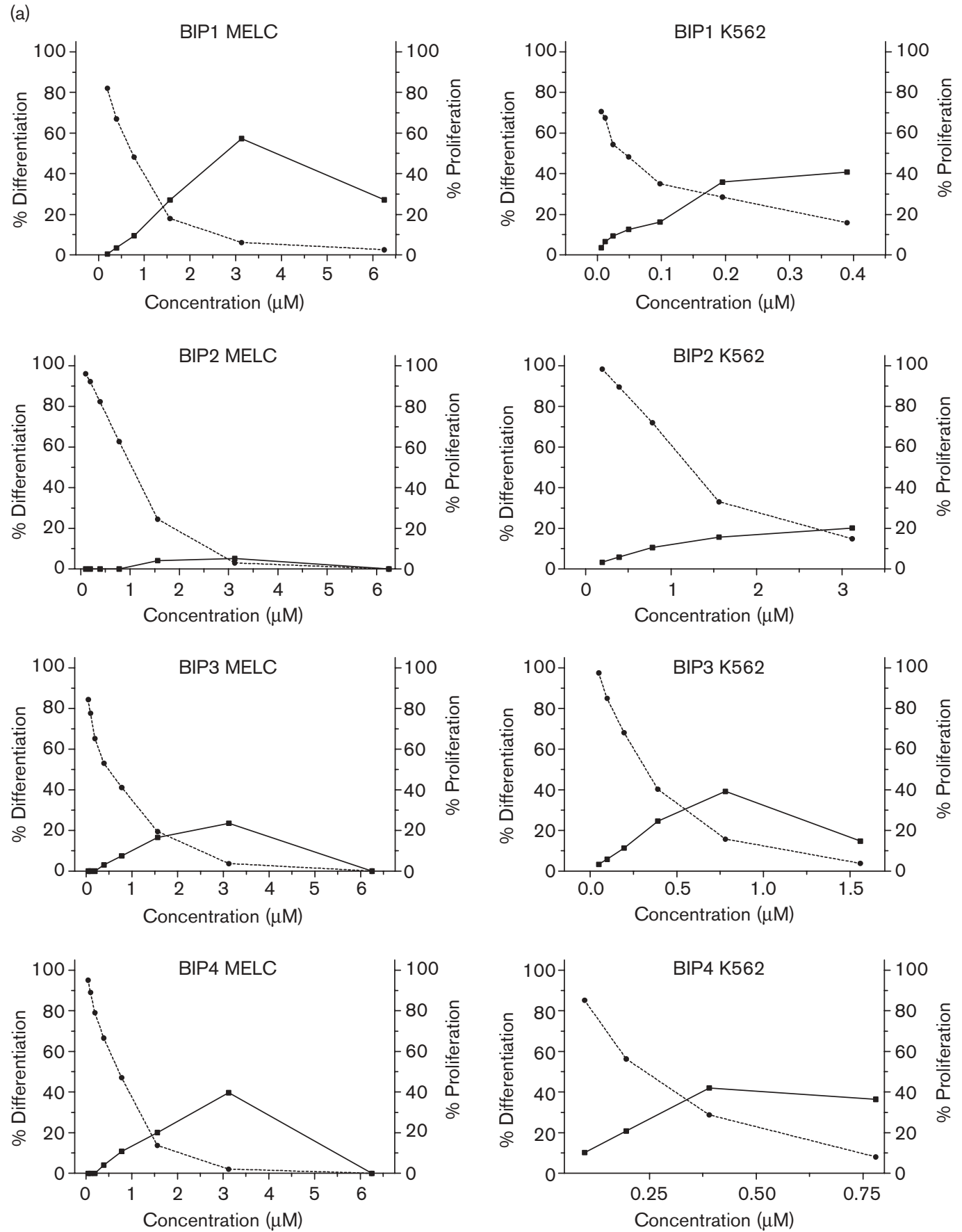
Fig. 2 Continued
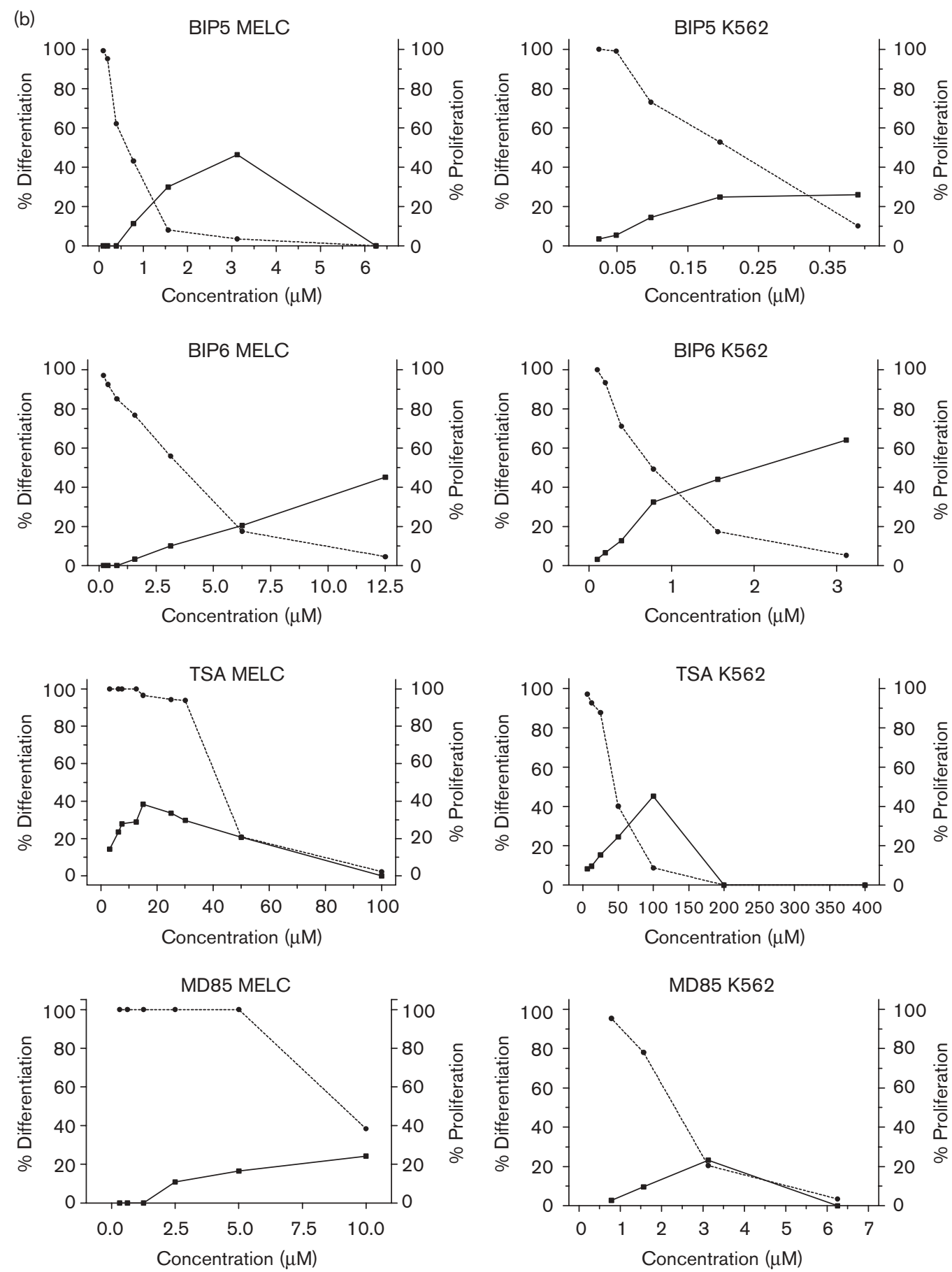

of the biphenylalanine BIP1 that is as potent as TSA in the human erythroleukemic K562 cell line. For most compounds the cellular activity was observed in the same concentration range as for enzyme-inhibitory activity, which supports the use of HDAC in vitro assays as screening tools for drug discovery. Therefore, we and others have also developed homogeneous assays for the determination of HDAC activity [39,40]. The lack of correlation with MS275 has been reported by another group before [31]. As MS275 shows in vitro enzyme inhibition in some papers in the low micromolar range which we and others could not reproduce, its activity might depend strongly on the enzyme preparation. 

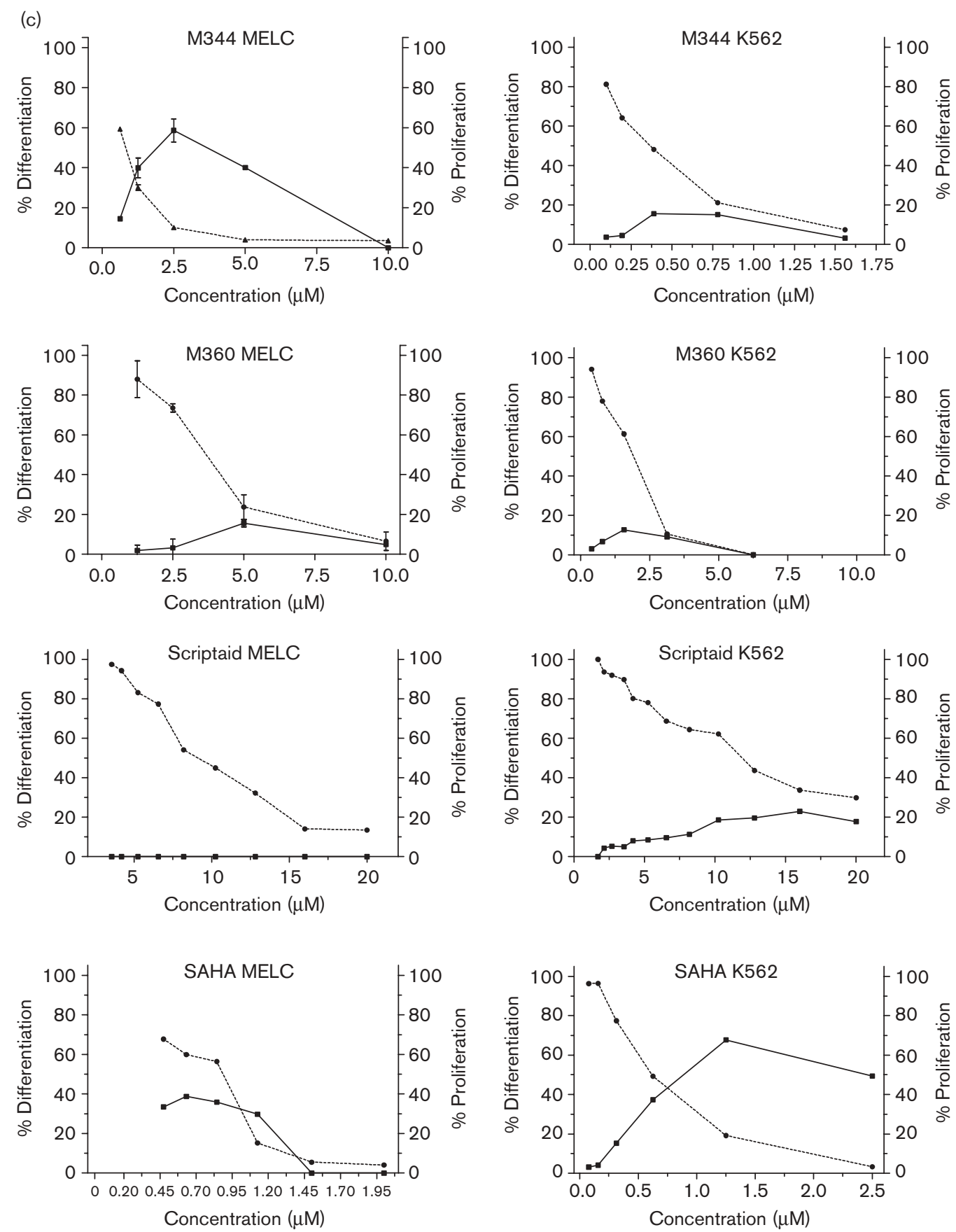

The patterns of induction of differentiation are more complex as the maximum levels of terminal cell differentiation achieved in the surviving cell population range from 0 to $68 \%$ among the various inhibitors. Not only are there differences between structurally very similar inhibitors in one cell type (e.g. M344 versus M360 in Friend cells), but some of the inhibitors have entirely different profiles of activity in the two erythroleukemic cell lines (e.g. M344 or MS275). The reasons for these observations remain unclear. A HDAC subtype selectivity of the various inhibitors is a possible explanation, and docking experiments with MD85, M344 and M360 in a homology model of human HDAC1 [36] supported the possibility of such a selectivity. Consequently, we have identified a difference in selectivity regarding HDAC1 and HDAC6 for M344 and M360 [30]. In this group of trichostatin analogs, stronger inhibition of HDAC6 is associated with stronger anti- 
Fig. 2 Continued
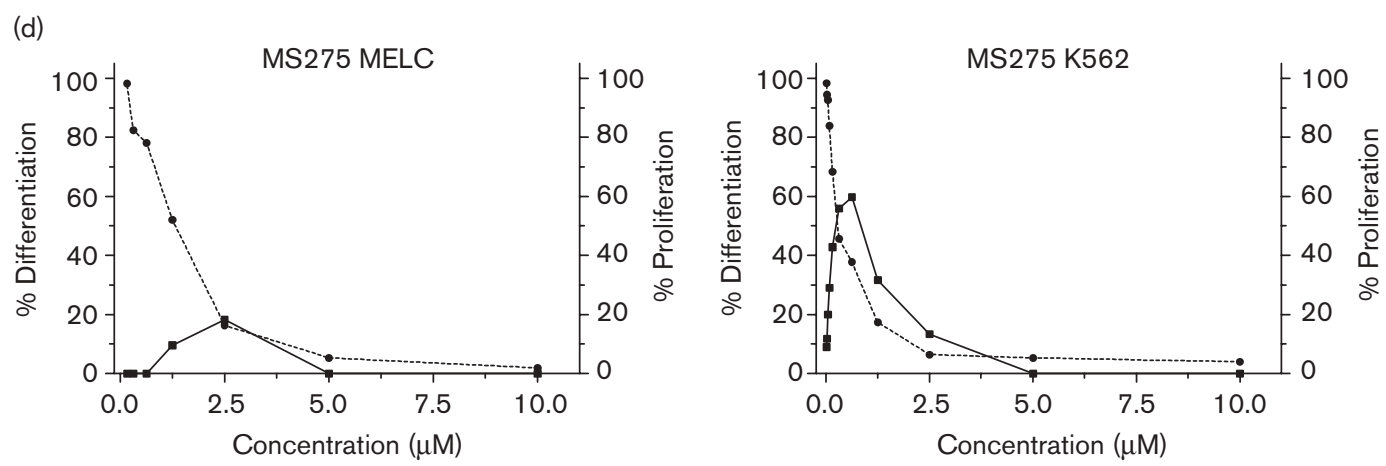

Induction of terminal cell differentiation (squares and solid lines) and inhibition of proliferation (circles and dotted lines) by HDAC inhibitors in Friend (MELC) and K562 cells. The graphs for the MELC results for TSA, MD85, M344, M360 [16], BIP1 and SAHA [13] are taken from our previous work. Reproduced with permission. (C) 1999 and 2002 American Chemical Society.

Fig. 3

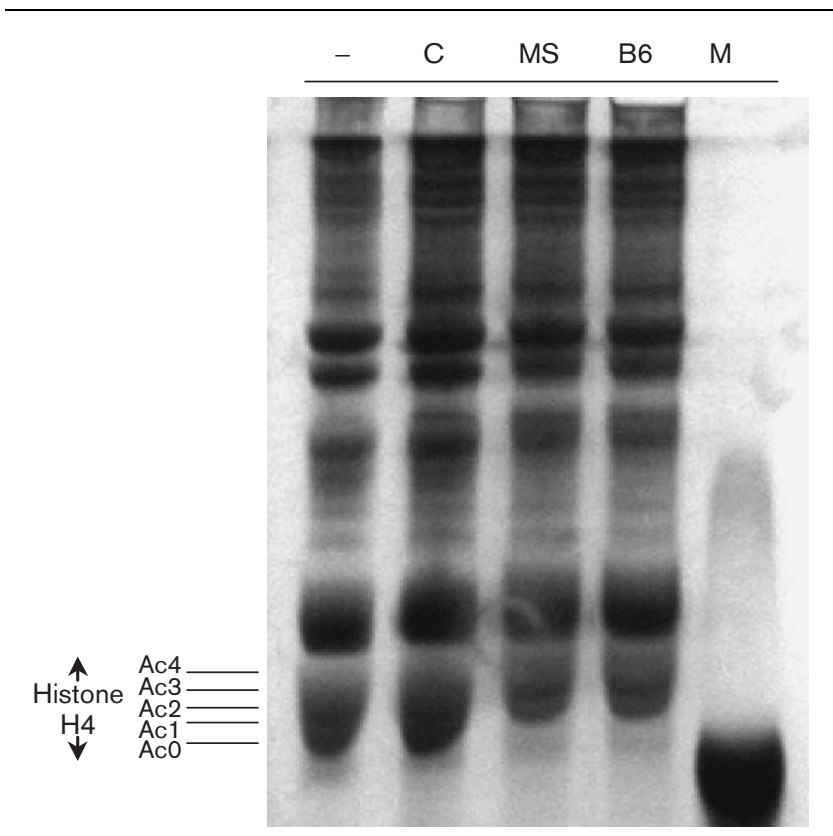

Acetylation status of histone $\mathrm{H} 4$ in $\mathrm{K} 562$ cells treated with BIP6 (B6, $1.56 \mu \mathrm{M})$ or MS275 (MS, $0.625 \mu \mathrm{M})$ for $12 \mathrm{~h}$. A '-' represents untreated cells, $\mathrm{C}$ stands for the solvent control treated with $0.1 \%$ DMSO.

Ac0-4: number of acetylated lysines. $\mathrm{M}$ : marker (cytochrome c). See Materials and methods for details.

proliferative activity and more potent induction of Friend cell differentiation (see Fig. 2). Additionally, the HDAC6selective M344 is also a better inducer of $\gamma$-globin expression [41] and leads to a more pronounced radiosensitization of cancer cells [42]. On the other hand, in the biaryl series, the weak inducer of differentiation (BIP2) is selective towards HDAC6, whereas the potent inducer (BIP6) is selective for HDAC3. TSA is unselective among the three subtypes, whereas TPX inhibits
Table 2 HDAC subtype selectivity

\begin{tabular}{lccc}
\hline Inhibitor & $\begin{array}{c}\text { FLAG-HDAC1 } \\
\left(\mathrm{IC}_{50}, \mathrm{nM}^{\mathrm{a}}\right)\end{array}$ & $\begin{array}{c}\text { FLAG-HDAC3 } \\
\left(\mathrm{IC}_{50}, \mathrm{nM}^{\mathrm{a}}\right)\end{array}$ & $\begin{array}{c}\text { FLAG-HDAC6 } \\
\left(\mathrm{IC}_{50}, \mathrm{nM}^{\mathrm{a}}\right)\end{array}$ \\
\hline BIP2 & 400 & 310 & 100 \\
BIP6 & 2540 & 790 & 2500 \\
MD85 & 390 & 390 & 330 \\
M344 & $250^{\mathrm{b}}$ & 480 & $90^{\mathrm{b}}$ \\
M360 $^{\mathrm{b}}$ & $110^{\mathrm{b}}$ & 410 & $170^{\mathrm{b}}$ \\
TSA $^{\mathrm{c}}$ & $2-6$ & 2 & 9 \\
TPX $^{\mathrm{c}}$ & $0.1-10$ & 100 & 360 \\
Butyrate $^{\mathrm{c}}$ & $0.1 \mathrm{mM}$ & $0.1 \mathrm{mM}$ & $6 \mathrm{mM}$ \\
\hline
\end{tabular}

aMean values of half-maximal inhibitory concentrations $\left(\mathrm{IC}_{50}\right)$ were generated from testing four to six concentrations in duplicate.

${ }^{\mathrm{b}}$ Data taken from [30].

'Data taken from $[43,44]$.

mainly HDAC1. The weak inhibitor butyrate leads to stronger inhibition of HDAC1 and HDAC3 (Table 2). Larger numbers of inhibitors have to be tested on more subtypes to further elucidate possible links between subtype selectivity and a profile of biological activity.

A differential downstream response to the gene activation induced by distinct inhibitors in the two cell lines may explain the varying results between Friend and K562 cells. We have shown before that, for example, BIP1 [13] or M344 [16] induce histone hyperacetylation at relevant concentrations, but an interaction with additional targets is also possible. As an example, BIP1 inhibits cell proliferation in the K562 cell line at 7-fold lower concentrations as compared to the inhibition in the enzyme assay.

\section{Conclusion}

Structural variations of a biphenylalanine HDAC inhibitor BIP1 have identified its $3^{\prime}$-methoxy analog BIP6 as a very good inducer of terminal cell differentiation in the K562 human erythroleukemic cell line. Compound BIP1 has an anti-proliferative potency in K562 cells that reaches that 
of the benchmark TSA. Based on these results, further modifications of its structure besides $3^{\prime}$ - or $4^{\prime}$-substitution are planned. The first comprehensive comparison of standard HDAC inhibitors in two cellular differentiation models further reveals striking differences among the various inhibitors and in the action of some of the inhibitors on different cell lines. This will stimulate mechanistic studies aimed at the elucidation of the molecular basis of action of these promising drug candidates. So far there is no clear link between HDAC subtype selectivity and good induction of differentiation.

\section{References}

1 Meinke PT, Liberator P. Histone deacetylase: a target for antiproliferative and antiprotozoal agents. Curr Med Chem 2001; 8:211-235.

2 Jung M. Inhibitors of histone deacetylase as new anticancer agents. Curr Med Chem 2001; 8:1505-1511.

3 Torchia J, Glass C, Rosenfeld MG. Co-activators and co-repressors in the integration of transcriptional responses. Curr Opin Cell Biol 1998; 10: 373-383.

4 Cress WD, Seto E. Histone deacetylases, transcriptional control, and cancer. J Cell Physiol 2000; 184:1-16.

5 Sambucetti LC, Fischer DD, Zabludoff S, Kwon PO, Chamberlin H, Trogani N, et al. Histone deacetylase inhibition selectively alters the activity and expression of cell cycle proteins leading to specific chromatin acetylation and antiproliferative effects. J Biol Chem 1999; 274:34940-34947.

6 Redner RL, Wang J, Liu JM. Chromatin remodeling and leukemia: new therapeutic paradigms. Blood 1999; 94:417-428.

7 Mahlknecht U, Hoelzer D. Histone acetylation modifiers in the pathogenesis of malignant disease. Mol Med 2000; 6:623-644.

8 Johnstone RW. Histone-deacetylase inhibitors: novel drugs for the treatment of cancer. Nat Rev Drug Discov 2002; 1:287-299.

9 Jung M. Histone deacetylases. In: La Thangue NB, Bandara LR (editors): Transcription Factors and Other Nuclear Proteins as Targets for Cancer Chemotherapy. Totowa, NJ: Humana Press; 2002, pp. 123-144.

10 Gray SG, Ekstrom TJ. The human histone deacetylase family. Exp Cell Res $2001 ; 262: 75-83$.

11 Yoshida M, Horinouchi S, Beppu T. Trichostatin A and trapoxin: novel chemical probes for the role of histone acetylation in chromatin structure and function. BioEssays 1995; 17:423-430.

12 Jung M, Hoffmann K, Brosch G, Loidl P. Analogues of trichostatin A and trapoxin B as histone deacetylase inhibitors. Bioorg Med Chem Lett 1997; 7:1655-1658.

13 Wittich S, Scherf H, Xie C, Brosch G, Loidl P, Gerhäuser C, et al. Structureactivity relationships on phenylalanine containing inhibitors of histone deacetylase-in-vitro enzyme inhibition, induction of differentiation and inhibition of proliferation in friend leukemic cells. J Med Chem 2002; 45:3296-3309.

14 Burk MJ, Lee JR, Martinez JP. A versatile tandem catalysis procedure for the preparation of novel amino acids and peptides. J Am Chem Soc 1994; 116:10847-10848.

15 Schmidt K, Gust R, Jung M. Inhibitors of histone deacetylase suppress the growth of MCF-7 breast cancer cells. Arch Pharm Pharm Med Chem 1999; 332:353-357.

16 Jung M, Brosch G, Kölle D, Scherf H, Gerhäuser C, Loidl P. Amide analogues of trichostatin $A$ as inhibitors of histone deacetylase and inducers of terminal cell differentiation. J Med Chem 1999; 42:4669-4679.

17 Hoffmann K, Brosch G, Loidl P, Jung M. A non-isotopic assay for histone deacetylase activity. Nucleic Acids Res 1999; 27:2057-2058.

18 Hoffmann K, Brosch G, Loidl P, Jung M. First non-radioactive assay for in vitro screening of histone deacetylase inhibitors. Pharmazie 2000; 55 601-606.

19 Heltweg B, Jung M. A micro plate reader based non-isotopic histone deacetylase activity assay. Anal Biochem 2002; 302:175-183.

20 Hoffmann K, Heltweg B, Jung M. Improvement and validation of the fluorescence-based histone deacetylase assay using an internal standard. Arch Pharm Pharm Med Chem 2001; 334:248-252.
21 Fischle W, Emiliani S, Hendzel MJ, Nagase T, Nomura N, Voelter W, et al. A new family of human histone deacetylases related to Saccharomyces cerevisiae HDA1p. J Biol Chem 1999; 274:11713-11720.

22 Richon VM, Rifkind RA, Marks PA. Differentiation of murine erythroleukemia cells (Friend leukemia cells). In: Cell Biology: A Laboratory Handbook. New York: Academic Press; 1994, pp. 213-217.

23 Kölle D, Brosch G, Lechner T, Lusser A, Loidl P. Biochemical methods for analysis of histone deacetylases. Methods 1998; 15:323-331.

24 Topliss JG. A manual method for applying the Hansch approach to drug design. J Med Chem 1977; 20:463-469.

25 Yoshida M, Kijima M, Akita M, Beppu T. Potent and specific inhibition of mammalian histone deacetylase both in vivo and in vitro by trichostatin $A$. J Biol Chem 1990; 265:17174-17179.

26 Su GH, Sohn TA, Ryu B, Kern SE. A novel histone deacetylase inhibitor identified by high-throughput transcriptional screening of a compound library. Cancer Res 2000; 60:3137-3142.

27 Richon VM, Emiliani S, Verdin E, Webb Y, Breslow R, Rifkind RA, et al. A class of hybrid polar inducers of transformed cell differentiation inhibits histone deacetylases. Proc Natl Acad Sci USA 1998; 95: 3003-3007.

28 Saito A, Yamashita T, Mariko Y, Nosaka Y, Tsuchiya K, Ando T, et al. A synthetic inhibitor of histone deacetylase, MS-27-275, with marked in vivo antitumor activity against human tumors. Proc Natl Acad Sci USA 1999; 96:4592-4597.

29 Suzuki T, Ando T, Tsuchiya K, Fukazawa N, Saito A, Mariko Y, et al. Synthesis and histone deacetylase inhibitory activity of new benzamide derivatives. J Med Chem 1999; 42:3001-3003.

30 Heltweg B, Dequiedt F, Marshall BL, Brauch C, Yoshida M, Nishino N, et al. Subtype selective substrates for histone deacetylases. J Med Chem 2004; 47:5235-5243.

31 Kraker AJ, Mizzen CA, Hartl BG, Miin J, Allis CD, Merriman RL. Modulation of histone acetylation by [4-(acetylamino)- $N$-(2-amino-phenyl) benzamide] in HCT-8 colon carcinoma. Mol Cancer Ther 2003; 2:401-408.

32 Yoshida M, Nomura S, Beppu T. Effects of trichostatins on differentiation of murine erythroleukemia cells. Cancer Res 1987; 47:3688-3691.

33 Lea MA, Randolph VM, Hodge SK. Induction of histone acetylation and growth regulation in eryrthroleukemia cells by 4-phenylbutyrate and structural analogs. Anticancer Res 1999; 19:1971-1976.

34 Marks PA, Richon VM, Kiyokawa H, Rifkind RA. Inducing differentiation of transformed cells with hybrid polar compounds: a cell cycle-dependent process. Proc Natl Acad Sci USA 1994; 91:10251-10254.

35 Park JH, Jung Y, Kim TY, Kim SG, Jong HS, Lee JW, et al. Class I histone deacetylase-selective novel synthetic inhibitors potently inhibit human tumor proliferation. Clin Cancer Res 2004; 10:5271-5281.

36 Remiszewski SW, Sambuccetti LC, Atadja P, Bair KW, Cornell WD, Green MA et al. Inhibitors of human histone deacetylase: synthesis, enzyme and cellular activity of straight chain hydroxamates. $J$ Med Chem 2002; 45: 753-757.

37 Finnin MS, Donigian JR, Cohen A, Richon VM, Rifkind RA, Marks PA, et al. Structures of a histone deacetylase homologue bound to the TSA and SAHA inhibitors. Nature 1999; 401:188-193.

38 Somoza JR, Skene RJ, Katz BA, Mol C, Ho JD, Jennings AJ, et al. Structural snapshots of human HDAC8 provide insights into the class I histone deacetylases. Structure $2004 ; 12: 1325-1334$.

39 Heltweg B, Jung M. A homogeneous non-isotopic assay for histone deacetylase activity. J Biomol Screen 2003; 8:89-95.

40 Wegener D, Wirsching F, Riester D, Schwienhorst A. A fluorogenic histone deacetylase assay well suited for high-throughput activity screening. Chem Biol 2003; 10:61-68.

$41 \mathrm{Cao} \mathrm{H}$, Stamatoyannopoulos $\mathrm{G}$, Jung $\mathrm{M}$. Induction of human gamma globin gene expression by histone deacetylase inhibitors. Blood 2004; 103:701-709.

42 Zhang $Y$, Jung M, Dritschilo A, Jung M. Enhancement of radiation sensitivity of human squamous carcinoma cells by histone deacetylase inhibitors. Radiat Res 2004; 161:667-674.

43 Emiliani S, Fischle W, Van Lint C, Al Abed Y, Verdin E. Characterization of a human rpd3 ortholog, HDAC3. Proc Natl Acad Sci USA 1998; 95: 2795-2800.

44 Furumai R, Komatsu Y, Nishino N, Khochbin S, Yoshida M, Horinouchi S. Potent histone deacetylase inhibitors built from trichostatin $\mathrm{A}$ and cyclic tetrapeptide antibiotics including trapoxin. Proc Natl Acad Sci USA 2001; 98:87-92. 